\title{
TEIVO TEIVAINEN
}

\section{DEMOKRATIA YLIOPISTOHALLINNOSSA: \\ KAMPPAILUJA KOLMIKANNASTA}

\section{KOLUMNI}

Helsingin yliopiston hallintorakennuksen katolla liehui vuonna 1990 musta lippu. Ilmensikö se anarkistisia vapausihanteita vai sattuiko ainejärjestö Limeksen lipuksi päätynyt pöytäliina muuten vain olemaan musta? Vallatussa hallintorakennuksessa liikkuneiden tarinoiden mukaan se hätkähdytti ainakin yliopiston vieraana ollutta neuvostoliittolaista valtuuskuntaa. Valtauksen tavoitteissa oli joka tapauksessa myös vahva porvarillisen demokratian perusvire.

Demokratia oli kaikessa monimerkityksisyydessään valtauksen tärkein iskusana. Sitä oli ilmassa muuallakin. Meille valtaajille demokratia tarkoitti ennen kaikkea professoreille keskittyneen päätösvallan kumoamista Helsingin yliopistossa. Maailmalla elettiin aikakautta, jota jotkut valtavirtatutkijat kutsuvat demokratisoitumisen kolmanneksi aalloksi. ${ }^{1}$ Itse olin opetellut demokratiakamppailuja parin edellisen vuoden ajan Latinalaisen Amerikan ja Yhdysvaltojen kaduilla ja kampuksilla. Toisille pari kuukautta aiemmin tapahtunut Berliinin muurin kaatuminen oli läheisempi innoittaja. Tokihan sen jälkeen yhden keisarillisen yliopiston professorivaltakin saataisiin kumoon.

Ilmoitimme pysyvämme vallatussa hallintorakennuksessa, kunnes saisimme riittävän selkeän viestin yliopistolain muuttamisesta eduskuntapuolueilta. Vaadimme lakia koskevien neuvottelujen avoimuuden lisäämistä ja eri yliopistolaisryhmien aiempaa tasaveroisempaa osallistumista yliopistohallintoon. Pääpaino valtaajilla oli opiskelijoiden äänivallan lisäämisessä, mutta periaatteisiin kuului myös muiden päätöksenteossa syrjittyjen ryhmien aseman parantaminen. Professorit ja opiskelijat tuntuivat monista itsestään selviltä ryhmäkategorioilta. Sen sijaan oli aluksi epäselvää, olisiko niiden lisäksi järkevää olla useampia kuin yksi muu ryhmä.

Lähtökohtanamme oli enimmäkseen, että yliopiston päättävissä elimissä tulisi vallita pääsääntöisesti tasajako ryhmien välillä. Mies ja ääni -nimellä aiemmin tunnettua periaatetta, jonka mukaan lukumääräisesti suurimalla ryhmällä eli opiskelijoilla olisi eniten edustajia, ei juurikaan nostettu keskusteluissa esiin. Osallistumisen eri muodoista puhuttiin valtauksen käytävillä, mutta vaatimusten kärki kohdistui ryhmäperustaiseen edustamiseen. Tavoitelluksi periaatteeksi alkoi vähitellen muovautua professorien, opiskelijoiden ja keskiryhmäksi nimetyn opetus- ja hallintoväen kunkin tasaveroinen edustus. Periaatteen nimeksi vakiintui kolmikanta. Kolmikantamaista edustamista oli joiltakin osin sovellettu Suomen yliopistoissa toki jo aiemminkin, mutta nimenomaan Helsingin yliopistossa professorien valta-asema oli vielä vankka.

Eduskuntapuolueiden edustajat marssivat innokkaasti luoksemme vallattuun hallintorakennukseen ja ilmaisivat tukensa. Maireita vieraita tuli myös opetusministeriöstä. Harri Holkerin sinipunahallitus suhtautui tavoitteisiimme eri tavalla kuin mies ja ääni -hanketta eduskunnan jarrutuskeskustelulla vuonna 1970 vastustaneet porvaripuolueet. Tavoitteillemme yliopiston demokrati- 
soimiseksi löytyi yllättävän laajasti tukea yliopiston ulkopuolelta. Samalla tuntui ilmeiseltä, että suurimmat esteet löytyivät oman talon sisältä, ennen kaikkea professorikunnan konservatiiveista.

Kun parin päivän valtauksen jälkeen poistuimme talosta, huusimme vuorotellen "voitto" ja "demokratia". Pian laki myös muutettiin. Riemuitsimme professorivallan murtumisesta. Kohtalaisen demokraattinen välivaihe Helsingin yliopistossa käynnistyi. Muualla Suomessa yliopistoja demokratisoivia muutoksia oli käynnistetty jo aiemmin.

Opiskelijoiden, keskiryhmien ja professorien kolmikantaan perustuva uusi päätöksentekomalli ei tietenkään luonut radikaalidemokraattista paratiisia. Lehmänkauppoja ja härskiäkin omien etujen ajamista esiintyi. Asioita päätettiin myös kolmikannan ulkopuolella. ${ }^{2}$ Silti uudistukset lisäsivät yhteisöllisyyttä, kun kolme pääryhmää sai edustajia laitos- ja tiedekuntaneuvostoihin. Valtauksessa tärkeässä roolissa ollut Tuomas Rantanen oli uuteen ylätason päätöksentekoelimeen konsistoriin valittujen opiskelijaedustajien joukossa pian uuden lain astuttua voimaan. Rantasen mukaan uudessa tilanteessa voitiin myös keskustella "aikaisemmin visusti torjutuista ongelmista, kuten esimerkiksi sukupuolten epätasa-arvopulmista yliopiston palkkausrakenteessa". ${ }^{3}$

Parikymmentä vuotta hallintorakennuksen voitollisen valtauksen jälkeen toimin Helsingin yliopiston yleisen valtio-opin laitoksen johtajana. Sain käytännön oppia myös siitä mitä merkitsee, kun johtajat olivat yhteisönsä valitsemia. Muodollisessa hierarkiassa yläpuolellani oleva dekaani yritti toisinaan maanitella minut tukemaan laitosyhteisöni selvän enemmistön mielestä huonoja uudistuksia. Niissä tilanteissa hänellä oli tapana muistuttaa olevansa esimieheni. Vastasin oikeuksieni ja velvollisuuksieni kumpuavan ensisijaisesti laitosyhteisöltä,joka oli minut edustajakseen valinnut.

Kolmikannan merkitys näkyi pian myös tiedekuntatasolla, kun tiedekuntaneuvosto päätti olla valitsematta dekaania uudelle kaudelle. Vaikka professorikollegojeni enemmistö äänesti hänen uudelleenvalintansa puolesta, keskiryhmien ja opiskelijoiden äänet ratkaisivat. Samalla saimme valtiotieteelliseen tiedekuntaan ensimmäistä kertaa naisdekaanin, sittemmin Tampereelle rehtoriksi siirtyneen Liisa Laakson.

Laitosjohtajakauteni osui vuonna 2009 hyväksyttyyn yliopistolakiin liittyneisiin kamppailuihin. Opetusministeriön ja yliopiston johdon puheissa alkoi vilistä autoritaarisia hallintomalleja markkinoivien konsulttien iskulauseita. Useimmin niissä esiintynyt sana oli johtaminen. Hallinnollisissa kokouksissa näytettiin kalvoja, joissa saatettiin kertoa yliopiston tehtävien uusjaosta niin, että opetuksen (ja sen johtamisen), tutkimuksen (ja sen johtamisen) sekä yhteiskunnallisen vuorovaikutuksen (ja sen johtamisen) rinnalla yliopistolla oli neljäs tehtävä: johtaminen.

Koska satuin olemaan sen laitoksen johtaja, jonne yliopiston johtajuuskoulutus oli keskitetty, toin toisinaan esille näkemyksiäni johtamisjargonia suoltavien puppugeneraattorien luonteesta. Kalvojen noloimmat verbaaliset ylilyönnit saattoivat hiukan laimentua, mutta johtajuuden korostaminen jatkui. Omaksutuissa johtajuusopeissa oletettiin lähes itsestäänselvyytenä, että hyvä johtajuus edellyttää henkilöstöryhmiä kolmikantaisesti edustavien neuvostojen päätösvallan rajoittamista.

Kolmikanta sai kritiikkiä myös muilta kuin teknokraateilta. Kasvatustieteen päivien yhteydessä vuonna 2009 osallistuin Akateeminen kysymys? -kirjan tiimoilta Tampereella järjestettyyn keskusteluun. Opetusministeriön hanke kolmikantaan perustuvien tiedekunta- ja laitosneuvostojen vallan vähentämiseksi oli jo edennyt aika pitkälle. Muistan häkeltyneeni, kun Jussi Vähämäki esitti tilaisuudessa täyslaidallisen kolmikantaa vastaan ja ilmoitti"minkä tahansa" olevan sitä parempi hallintomalli. Kirjassa hän esitti, että "juuri kolmikanta teki osaltaan mahdolliseksi uuden yliopistolain valmistelun yliopistolaisia kuulematta ns. etujärjestöjen tasolla”. 
Vallankumouksen hedelmiä-blogissa siteerataan Vähämäkeä seuraavasti:

Haluammeko muiden tekemää demokratiaa? Ikään kuin yliopiston hallintomalli demokratisoituisi tuomalla vielä yksi fraktio taistelemaan toisten kanssa. Maailma on todella nurinniskoin, kun kuulee jopa joidenkin opiskelijoiden aivan vakavissaan puolustavan kolmikantaa demokraattisena mallina. ${ }^{4}$

Oletan, että Vähämäen pyrkimyksenä oli tuoda esiin muunlaista osallistumista korostavien toimintamallien paremmuus suhteessa edustuksellisiin neuvostoihin. Yliopistodemokratian tulevaisuuden kannalta kyse on tärkeästä keskustelusta, jolle Vähämäen kirjoitukset tarjoavat useita oivalluksia. ${ }^{5}$ En voinut silti välttyä ajatukselta, että kyse oli yksinkertaistavasta historiantulkinnasta. Siinä määrin kun kolmikanta oli ainakin omassa yliopistossani tulosta vuoden 1990 hallintorakennuksen valtaukseen liittyvistä kamppailuista, minun oli vaikea mieltää sitä vain "muiden" tekemäksi.

Uskoin myös, että vuonna 2009 kolmikantaedustuksen jyrkkä vastustaminen auttaisi viemään yliopistojen hallintoa kohti autoritaarista vallan keskittämistä. Edustuksellisiin elimiin liittyy monia ongelmia ja hierarkioita, joiden purkaminen on tärkeää radikaalisti demokraattiselle politiikalle. Historiasta löytyy kuitenkin myös esimerkkejä siitä, miten edustuksellisten demokratiamekanismien purkaminen on johtanut autoritaaristen johtamismallien esiinmarssiin. Kolmikannan kohtalo yliopistohallinnossa on tästä yksi esimerkki.

Vaikka vuoden 2010 alussa voimaan tullut yliopistolaki romahdutti osan yliopistodemokratiasta, se myös jätti merkittävää liikkumavaraa yliopistojen sisäisille johtosäännöille ja muille normeille. Helsingin yliopistossa kiihkeimmät kamppailut kolmikannasta käytiin keskusteltaessa dekaanien ja laitosjohtajien valintatavasta. Kun uuden yliopistolain linjaukset olivat vuonna 2009 selvillä, yliopiston johto alkoi kampanjoida valintatavan muutoksen puolesta.

Päätösvaltaa pyrittiin virtaviivaistamaan niin, että rehtori valitsisi dekaanit ja dekaanit valitsisivat laitosjohtajat. Laitokset ja tiedekunnat eivät siis enää saisi päättää kolmikantaneuvostojensa välityksellä johtajiensa valinnasta. Kun aluksi epämääräisenä esitetty tiukan hierarkkinen valintamenettely alkoi saada laajaa vastustusta, keskusteluun tuli myös monenlaisia hybridimalleja. Niissä pyöriteltiin kysymyksiä siitä, tulisiko neuvostojen saada tehdä johtajavalinnoissa päätös, esitys vai lausua mielipiteensä.

Neuvostoilta oli jo viety suuri osa niiden muusta päätösvallasta, sillä uusien johtajaoppien mukaisesti valtaa oli keskitetty yksilöjohtajille. Kuulin Helsingin yliopiston kehitysjohtajan Ulla Mansikkamäen perustelevan tätä toistuvasti sillä, että uusi yliopistolaki lisää yliopistojen taloudellista vastuuta ja "eiväthän kollektiivit voi kantaa taloudellista vastuuta". Jo aiemmin henkilöstöjohtaja Kira Ukkonen oli korostanut, että"niillä, joilla on vastuu toiminnasta, täytyy olla valtaa tehdä päätöksiä"6.

Esimerkiksi tiedekuntaneuvostojen tärkeimmäksi tehtäväksi vaikutti jäävän väitöskirjojen arvostelu ja kerran neljässä vuodessa tapahtuva dekaanin valinta. Kun sitten jälkimmäinenkin uhattiin viedä niiltä pois, mitta tuli monella täyteen. Yliopistojohdon muotoilemassa kompromissiehdotuksessa tiedekuntaneuvostot olisivat tehneet rehtorille esityksen useammasta dekaaniehdokkaasta, joista sitten rehtori olisi valinnut mieleisimmän.

Tuossa tilanteessa Helsingin yliopiston johto lopulta taipui kiivaiden väittelyjen jälkeen jättämään johtajavalinnat ensisijaisesti neuvostojen vastuulle. Tiedekuntaneuvoston tehtäväksi määritettiin vuoden 2009 johtosäännössä "valita dekaani ja esittää valinta rehtorin vahvistettavaksi". 
Vaikka me kolmikannan puolustajat emme juhlineet ja julistaneet voittoa vuoden 1990 hallintorakennuksen valtaajien tapaan, huokaisimme helpotuksesta. Olimme demokratian purkamisvimman keskellä saaneet merkittävän torjuntavoiton.

Vuonna 2014 Helsingin yliopiston johto nosti johtajavalintakysymyksen esiin aiempaa päätäväisemmin. Perusteluksi esitettiin esimerkiksi yliopiston rekrytointijärjestelmän muuttamista sellaisella oletuksella, että neuvostojen päätösvalta olisi ristiriidassa joustavamman rekrytoinnin kanssa. Muutoksen tueksi esitettiin lisäksi johtamisketjun hierarkisoinnin sitouttavaa vaikutusta. ${ }^{7}$

Hallintojohdossa rakennettiin sopivissa tilanteissa myös tarinaa, jossa Helsingin yliopiston johtosääntö olisi nyt vihdoin mukautettava uuden yliopistolain pykäliin. Kävin hallintojohdon kanssa tiukkoja keskusteluja siitä, olivatko he oikeasti sitä mieltä, että yliopistolaki olisi edellyttänyt esimerkiksi dekaanivalintojen siirtämistä pois kolmikantaneuvostoilta. Oma näkemykseni oli ja on edelleen, että laki ei sitä edellyttänyt. Tulin surulliseksi siitä, että yliopistossani tärkeitä päätöksiä tunnuttiin perustelevan välillä myös älyllisesti epärehellisellä tavalla.

Yliopiston eri ryhmien kantoja asiaan on vaikea arvioida tarkasti, mutta demokratian purkaminen sai vuonna 2014 jälleen laajaa vastustusta. Professorikunnan näkemyksiä pääsin seuraamaan esimerkiksi suuren konsistorin kokouksessa. Helsingin yliopiston suuri konsistori on kaikkien professorien muodostama kokous, jolla ei ole varsinaista päätösvaltaa. Tavallaan kyse on siitä vanhan professorivallan ytimestä, jonka aseman mursimme vuoden 1990 hallintorakennuksen valtauksella. Jonkun mielestä saattaa olla hassua, että Helsingin yliopiston professorikokouksissa on viime vuosina korostettu kolmikantaan perustuvien neuvostojen merkitystä, vaikka juuri niiden muodostaminen mursi professorien aiemman valta-aseman.

Vuonna 2014 suuren konsistorin kokouksessa keskusteltiin yliopiston johdon tekemästä esityksestä uudeksi johtosäännöksi. Lähes koko keskustelu käsitteli dekaanien ja laitosjohtajien valintatapaa. Kokouksen huipentuma tuli hiukan ennen loppua, kun osallistujat nostivat käsiä pystyyn osoittaakseen kannatustaan esillä olleille valintatavoille. Mitän̈n virallista ääntenlaskua ei suoritettu, mutta tahdonilmaus oli poikkeuksellisen selvä.

Silloin voimassa ollut malli, jossa kolmikantaneuvostot valitsivat johtajansa, sai arviolta hiukan yli kahden kolmasosan professoreista ilmaisemaan kannatuksensa nostamalla kättä. ${ }^{8}$ Yliopiston johdon ehdotuksen kannattajaksi sen sijaan ei kättään nostamalla ilmoittautunut yksikään paikalla olevista professoreista. Ei siis kukaan. Kokouksessa oli siinä vaiheessa noin 70 professoria. En usko heidän muodostaneen kovinkaan voimakkaasti yliopiston koko professorikunnan näkemyksistä poikkeavaa otosta. Kolmikantamallia puolustaneilla näkemyksillä oli ollut selvästi suurin kannatus myös muissa professorien keskuudessa tehdyissä selvityksissä.

Kokouksessa kuultiin myös puheenvuoroja, joissa etsittiin erilaisia kompromisseja kolmikantamallin ja johdon esityksen väliltä. Monet kolmikantamallin puolustajatkin toivat toistuvasti esiin, että eivät suinkaan pitäneet silloista johtosääntöä parhaana mahdollisena. Tahdonilmaus koskien johtajien valintatapaa oli kuitenkin harvinaisen selkeä, jopa siis yliopiston konservatiivisimpana pidetyn ryhmän eli professorien keskuudessa. Helsingin yliopiston ylioppilaskunnan hallituksen entiseltä jäseneltä Esa Tiusaselta kuulin, että myös valtaosa ylioppilaskunnan hallituksen tietoon tulleista opiskelijakannoista oli dekaanien valintauudistuksen suhteen kriittisiä.

Silti yliopiston johto runnoi uudistuksen läpi. Olisi kiinnostavaa saada perinpohjainen selvitys siitä, minkälaisen tiedon ja millaisten lakitulkintojen varassa johtosäännöstä päättänyt yliopiston hallitus lopulta päätyi purkamaan kolmikantaa entisestään. Hallituksessahan on yliopiston ulkoisten jäsenten lisäksi myös kaikkien perinteisten kolmikantaryhmien edustajia. 
Vaikka osa yliopistoväestä saattaa olla jo jokseenkin alistuneita siihen, että lopulta saimme nykyisen autoritaarisen hallintomallin, tilannetta kohtaan on myös laajaa tyytymättömyyttä. Tyytymättömyyden muodot vaihtelevat. Välillä se on purkautunut mielenosoituksiksi ja Helsingin yliopiston tilojen uusiksi valtauksiksi. Autonomishenkiset valtaajaradikaalit ja maltillisina pidetyt akateemiset ammattiyhdistykset eivät ole juurikaan löytäneet suoraa keskusteluyhteyttä, mutta merkkejä uudenlaisesta keskinäisymmärryksestä on ollut ilmassa.

Vuoden 2016 jälkipuoliskolla julkisuuteen on tullut useampikin selvitys, joissa yliopistolaisten laaja tyytymättömyys uusiin johtamisjärjestelyihin on noussut esiin. Erityisen voimakasta tyytymättömyys on ollut Helsingin yliopistossa. Opetus- ja kulttuuriministeriön toimeksiannosta tehdyssä yliopistolain vaikutusten arvioinnissa nousi syyskuussa 2016 julkisuuteen, että yliopistoyhteisö kokee itsensä syrjäytetyksi päätöksenteosta. Vaikka ministeriön tilaamaa arviointia kohtaan oli monenlaisia epäluuloja, sen tulokset antoivat tältä osin lisäpontta vaatimuksille yliopiston demokratisoinnista. ${ }^{9}$

Tuossa yliopistolain vaikutusten arvioinnissa oli Helsingin yliopiston osalta sellainen virhe, että siinä arvioitiin tilannetta jo pari vuotta aiemmin vanhentuneen johtosäännön perusteella. Selvityksen näkemys yliopistoyhteisön etääntymisestä päätöksenteosta perustui siis sellaiseen johtosääntöön, joka oli kolmikantapäätöksenteon kannalta merkittävästi nykyjohtosääntöä vähemmän autoritaarinen. Mikäli selvitys olisi perustanut arvionsa Helsingin yliopiston ajantasaiseen johtosääntöön, päätösvallan etääntyminen henkilökunnasta olisi saattanut näyttää vieläkin rajummalta. ${ }^{10}$

Viime vuosien muutokset ovat olleet niin selvästi henkilöstön ja opiskelijoiden vaikutusmahdollisuuksia tukahduttavia, että niiden vastustaminen yhdistää kohtalaisen laajoja piirejä. Nykyistä demokraattisemman yliopistohallinnon yksityiskohdista sen sijaan saattaa olla monenlaisia epäselvyyksiä ja erimielisyyksiä. Keskustelu saattaa kuitenkin olla jälleen vilkastumassa.

Vaihtoehtoja autoritaariselle hallintomallille on jo tullut esiin. Huhtikuussa 2016 olin mukana ensi alkuun professorikapinan nimellä tunnetussa aloitteessa. Siinä aluksi 12 professoria ja pian moni muukin vaati demokraattisia uudistuksia yliopistohallintoon. ${ }^{11}$ Lokakuussa 2016 ilmestyi Yliopistokäänne-ryhmän piirissä valmisteltu ja neljän kollegani työstämä kirja Uusi yliopistolaki 2020 , jossa on hahmoteltu nykyistä demokraattisemman yliopiston suuntaviivoja ${ }^{12}$. Olen havainnut merkkejä myös siitä, että aikoinaan yliopistojen demokraattisia uudistuksia vastustanut Professoriliitto saattaisi ottaa kantaa yliopistolain muuttamiseksi ja mitä ilmeisimmin ainakin astetta demokraattisempaan suuntaan.

Osalla professorikuntaa korostuu kannanotoissa keskeisenä ajatus, että vallan karkaaminen nimenomaan oppiaineiden oppineimmilta asiantuntijoilta (eli professoreilta itseltään) on viimeaikaisen kehityksen pääongelma. Yksi tähän liittyvä ja näkemyksiä ainakin hiukan jakava kysymys on, missä määrin opiskelijoiden tulisi osallistua opetushenkilökunnan valintoihin.

Vuotta 2010 edeltäneessä kolmikannassa opiskelijat äänestivät tiedekuntaneuvostoissa tasaveroisina jäseninä, kun lehtoreita tai professoreita valittiin. Professorien valinta oli Helsingin yliopistossa muodollisesti kanslerin päätösvallassa, mutta poikkeamia tiedekuntaneuvoston aiemmasta päätöksestä tapahtui harvoin. Itseäni koskevassa valinnassa näin sattui kerran ${ }^{13}$. Olen joka tapauksessa pitänyt opiskelijoiden osallistumista päätöksentekoon nimitysasioissakin järkevänä, sillä varsinaiset asiantuntijalausunnot on tilattu akateemisesti oppineilta henkilöiltä. Osa kollegoistani on sitä mieltä, että opiskelijoiden äänivallan tulisi sen sijaan kohdistua rajattuun joukkoon "heille sopivia" asioita, esimerkiksi professorien tai lehtoreiden valinnassa lähinnä opetusnäytteen arviointiin eikä muuhun varsinaiseen päätöksentekoon.

Kolmikantaedustuksen mahdollisen elvyttämisen lisäksi demokraattisen yliopiston mahdollisuuksia on syytä pohtia myös muiden osallistumisen muotojen ja vapauden näkökulmasta. 
Esimerkiksi akateemista vapautta voi pitää eräänlaisena kolmikannan anarkistisena rajoitteena. Akateemista vapautta ei ole syytä koskaan liiaksi säännellä, vaikka sääntelijän edustavuus olisi hilattu huippuunsa. Lisäksi työsuhdeturvan vahvistamiseen liittyvien kamppailujen merkitys on tullut irtisanomisten kaudella monelle aiempaa ilmeisemmäksi. Niiden suhteen ammattiliitoilla on tärkeä rooli, mutta pelkästään liittojen varaan ei tässäkään asiassa kannata tuudittautua. Demokraattinen yliopisto on mahdollinen vain jos sen jäsenet luovat sinne demokraattisia käytäntöjä monin eri tavoin.

\section{VIITTEET}

1. Itse termi Third Wave of Democratization oli erityisesti Samuel Huntingtonin kaltaisten konservatiivitutkijoiden suosiossa. Hiukan laajempana ilmiönä 1980-luvun loppupuolen muutosten demokraattinen suunta esimerkiksi Chilessä tai DDR:ssä oli kuitenkin kohtalaisen laajasti hyväksytty asia. Ks. Samuel P. Huntington: The Third Wave: Democratization in the Late Twentieth Century. University of Oklahoma Press, 1993.

2. Sukupuoleen liittyvistä valta-asetelmista kolmikantakaudella ks. esim. Johanna Kantola: Mykät, kuurot ja kadotetut: sukupuolten välinen tasa-arvo Helsingin yliopiston valtio-opin laitoksella. Acta Politica, Helsingin yliopisto, 2005.

3. Tuomas Rantanen: "Barrikadeja yliopistolla". Voima 24.2.2009, http://uusi.voima.fi/blogikirjoitus/2009/barrikadejayliopistolla/

4. "Työväen sivistys". Vallankumouksen hedelmiä http://www.vallankumous.org/exblogi/vallankumous.blogsome.com/category/opiskelu/index.html

5. Olen käsitellyt edustuksellisuuden merkitystä autonomisen ja anarkistisen poliittisen teorian yhteydessä viimeksi artikkelissa Teivo Teivainen: "Occupy Representation and Democratize Prefiguration: Speaking for Others in Global Justice Movements", Capital \& Class, February 2016 40: 19-36.

6. Virve Pohjanpalo ja Reetta Vairimaa: "Yliopisto uusiks". Yliopistolainen 3, 2008, http://www.helsinki.fi/yliopistolainen/2008/3/artikkeli.htm

7. Valtiotieteellisen tiedekunnan dekaani Liisa Laakso arvioi valintamallin merkitystä luottamukselle blogikirjoituksessaan "Johtosääntöuudistus: dekaanien ja laitosten johtajien valinta". Valtiotieteellisen tiedekunnan dekaanin blogi 15.10.2014, http://blogs.helsinki.fi/lilaakso/?p=139

8. Oma arvioni on sikäli maltillinen, että joidenkin paikalla olleiden professorien mielestä kyse oli vielä suuremmasta enemmistöstä.

9. Yliopistolakiuudistuksen vaikutusten arviointi. Opetus- ja kulttuuriministeriön julkaisuja 2016:30. http://julkaisut.valtioneuvosto.fi/handle/10024/75416

10. Kiitän Esa Tiusasta huomioni kiinnittämisestä tähän virheeseen.

11."Professorikapina vaatii yliopistolain ripeää muutosta". Helsingin Sanomat 4.4.2016, http://www.hs.fi/kotimaa/ a1459742714761

12. Visa Heinonen, Jukka Kekkonen, Veli-Pekka Lehto, Heikki Patomäki ja Yliopistokäänne-työryhmä: Uusi yliopistolaki 2020. Into, Helsinki 2016.

13. Molemmilla kerroilla, kun olen hakenut (kahdesta eri tiedekunnasta) Helsingin yliopiston professoriksi, kolmikantainen tiedekuntaneuvosto on esittänyt valintaani. Ensimmäisellä kerralla kansleri käytti oikeuttaan sivuuttaa neuvoston esitys. 